\title{
Pelatihan Pemasaran Online Usaha Home Industry Kerajinan Semen Pekon Keputran Kabupaten Pringsewu
}

\author{
Bernadhita Herindri Samodera Utami*, Miswan Gumanti, Novi Ayu Kristiana Dewi \\ Prodi Sistem Informasi, STMIK Pringsewu, Jl. Wisma Rini No. 9, Pringsewu, Lampung, \\ Indonesia
}

*Email Korespondensi: ind.indri1245@gmail.com dan 08197940176

Diterima: Februari 2021; Revisi: April 2021; Diterbitkan: Mei 2021

\begin{abstract}
Abstrak
Kemudahan berbisnis melalui pemanfaatan media sosial mendorong penulis dan tim untuk mengadakan kegiatan pengabdian berupa pendampingan dan pelatihan bagi pengusaha home industry kerajinan semen di Desa Keputran, Kecamatan Sukoharjo, Kabupaten Pringsewu, Lampung. Salah satu potensi perkembangan teknologi yang dapat dimanfaatkan sebagai media pemasaran adalah media sosial yang dapat menembus batas jarak, ruang, dan waktu. Kegiatan pelatihan ini bertujuan untuk memberikan manfaat bagi para pengusaha dalam memasarkan produk yang akhirnya memberikan dampak bertambahnya mitra, pesanan, dan juga pendapatan. Dengan bertambahnya pendapatan maka kegiatan usaha terus berputar dengan siklus yang normal bahkan mengalami trend yang semakin meningkat. Hasil akhir yang ingin dicapai adalah bertambahnya taraf hidup pengusaha dan juga warga di sekitar Desa Keputran, Kecamatan Sukoharjo, Kabupaten Pringsewu, Lampung.
\end{abstract}

Kata Kunci: pemasaran online; home industry; kerajinan semen

\section{Online Marketing Training for Home Industry of Cement Crafts in Pekon Keputran, Pringsewu Regency}

\begin{abstract}
The ease of doing business through social media encourages writers and the team to hold service activities in the form of mentoring and training for the cement craft home industry in Keputran Village, Sukoharjo District, Pringsewu Regency, Lampung. One of the potential developments in technology that can be used as a marketing medium is social media that can penetrate the boundaries of distance, space, and time. This training aims to provide benefits for entrepreneurs in marketing products. With the increase in income, business activities continue to rotate with a normal cycle and even experience an increasing trend. The final result to be achieved is increasing the standard of living of entrepreneurs and also residents around Keputran Village, Sukoharjo District, Pringsewu Regency, Lampung.
\end{abstract}

Keywords: online marketing; home industry; cements craft

How to Cite: Utami, B., H., S., Gumanti, M., \& Dewi, N. A. K. (2021). Pelatihan Pemasaran Online Usaha Home Industry Kerajinan Semen Pekon Keputran Kabupaten Pringsewu. Lumbung Inovasi: Jurnal Pengabdian Kepada Masyarakat, 6(1), 10-15. https://doi.org/10.36312/linov.v6i1.475

https://doi.org/10.36312/linov.v6i1.469

Copyright $\odot$ 2021, Utami et al This is an open-access article under the CC-BY License.

\section{PENDAHULUAN}

Industri adalah suatu kegiatan pengolahan bahan mentah atau barang setengah jadi menjadi barang yang memiliki nilai tambah, baik secara guna atau ekonomi. Salah satu jenis industri adalah industri rumahan atau yang dikenal dengan home industry yaitu usaha kecil dan menengah (UKM) yang memanfaatkan tempat usaha berupa rumah tangga dengan jumlah karyawan yang terbatas (Ananda \& Ashaluddin, 2016). Tresnati \& Maharani (2014) menyatakan bahwa UKM merupakan wadah kegiatan usaha bersama bagi produsen dan konsumen yang menempati posisi strategis dalam upaya percepatan perubahan struktural 
dalam upaya peningkatkan taraf hidup rakyat banyak. Menurut Panggabean dkk. (2019) bahwa home industry memberikan peran yang sangat penting dalam menopang perokonomian negara karena sebagai motor penggerak perekonomian rakyat dalam menanggulangi kemiskinan. Adapun peran home industry tersebut seperti penyedia lapangan kerja, pemerataan pendapatan, dan pembangunan ekonomi di pedesaan.

Home industry dapat dikategorikan sebagai bentuk kewirausahaan karena memenuhi karakteristik seperti keinginan untuk bertahan hidup, berpikir kreatif, berpikir untuk menemukan sesuatu yang lebih baik dengan mengembangkan apa yang dimiliki, berpikir visioner untuk menemukan sesuatu yang baru dan berbeda, dan mengandung unsur pengambilan risiko (Hendro, 2011). Dengan berwirausaha maka seseorang akan menjadi lebih mandiri secara ekonomi, kreatif untuk menemukan ide dan konsep baru, serta inovatif untuk menghasilkan barang ataupun jasa agar bisnisnya dapat menciptakan peluang pasar untuk diterima masyarakat (Garaika, 2020).

Dunia kewirausahaan, pasar, persaingan, serta perilaku konsumen terus mengalami perubahan yang semakin meningkat karena perkembangan teknologi yang telah mengubah segalanya baik dari segi produksi maupun pemasaran. Perubahan dunia usaha yang semakin cepat dipengaruhi oleh munculnya teknologi digital dalam dunia informasi, telekomunikasi, dan kehidupan sosial seseorang. Dampaknya adalah banyaknya peluang bisnis baru yang tumbuh dengan memanfaatkan perkembangan teknologi digital sebagai kunci utama dalam core business-nya. Perkembangan teknologi yang semakin pesat dan gaya hidup masyarakat menjadikan teknologi digital sebagai pilihan utama dalam menunjang pemenuhan kebutuhan hidup (Danuri, 2019).

Kemajuan teknologi serta ketatnya persaingan pada dunia bisnis telah mendorong semakin berkembangnya media bisnis online dalam kegiatan promosi yang semula melalui iklan di TV dan baliho yang dipasang di jalan menjadi promosi online melalui internet. Fenomena ini disebabkan perubahan gaya dan pola hidup yang terjadi pada konsumen dalam kehidupan sosialnya. Kehadiran situs jejaring sosial seperti Facebook, Twitter, dan Instagram mampu merubah strategi pemasaran barang dan jasa menjadi lebih efektif dan efesien. Dengan demikian para pelaku usaha harus membenahi strategi pemasaran agar dapat bersaing di era sistem perdagangan bebas untuk meningkatkan penjualan.

Kemudahan berbisnis melalui pemanfaatan media sosial ini mendorong penulis dan tim untuk mengadakan kegiatan pengabdian berupa pendampingan dan pelatihan bagi pengusaha home industry kerajinan semen di Desa Keputran, Kecamatan Sukoharjo, Kabupaten Pringsewu, Lampung. Pekon Keputran adalah desa yang terletak di Kecamatan Sukoharjo, Kabupaten Pringsewu, Lampung. Pekon Keputran secara resmi berdiri pada tahun 1974, yang sebelumnya merupakan bagian wilayah dari Pekon Sukoharjo III yang awalnya merupakan suatu kawasan hutan yang dihuni oleh penduduk asli suku Lampung, kemudian sekitar tahun 1950an datang transmigran dari suku jawa dan membuka kawasan hutan menjadi lahan pertanian dan perkebunan. Secara geografis, Kecamatan Sukoharjo memiliki sungai besar yang bernama Way Sekampung. Sungai ini menghasilkan tambang pasir yang berkualitas baik, maka tak heran warga di sekitar Kecamatan Sukoharjo memanfaatkan pasir tersebut sebagai campuran pembuatan kerajinan semen seperti paving block, batako, dan batu nisan.

Menurut Risal (2017) ada beberapa faktor penghambat perkembangan home industry di Indonesia, antara lain kurangnya modal usaha, manajemen usaha yang belum bagus, SDM yang kurang terampil, serta pemasaran yang belum maksimal. Adapaun faktor penghambat yang ditemukan pada home industry kerajinan semen di Desa Keputran adalah keterbatasan pengetahuan teknologi dari para pengusaha sehingga menyebabkan area pemasaran masih terbatas di sekitar wilayah Desa Keputran. Padahal pemasaran (marketing) adalah aktivitas yang bertujuan untuk mengomunikasikan, menyampaikan, dan menawarkan produk yang bernilai bagi pelanggan maupun mitra, dan masyarakat umum. Salah satu potensi perkembangan teknologi yang dapat dimanfaatkan sebagai media pemasaran adalah media sosial yang dapat menembus batas jarak, ruang, dan waktu. Seseorang dapat dengan mudah menghubungi koleganya yang berada di luar provinsi bahkan luar negeri dengan akses internet. Dengan berbekal menyebarkan dan mengimplementasikan ilmu yang berguna bagi warga masyarakat, maka tim pengabdian terpanggil untuk hadir di tengah-tengah pengusaha 
home industry kerajinan semen di Desa Keputran selama kurang lebih empat pekan. Kegiatan pelatihan ini bertujuan untuk memberikan manfaat bagi para pengusaha dalam memasarkan produk yang akhirnya memberikan dampak bertambahnya mitra, pesanan, dan juga pendapatan. Dengan bertambahnya pendapatan maka kegiatan usaha terus berputar dengan siklus yang normal bahkan mengalami trend yang semakin meningkat. Hasil akhir yang ingin dicapai adalah terbukanya wawasan pelaku home industry di Pekon Keputran dalam memanfaatkan media sosial sebagai media pemasaran barang secara online untuk memperluas area jangkauan promosi sehingga dapat meningkatkan hasil penjualan yang secara langsung juga dapat meningkatkan taraf hidup pengusaha dan juga warga di sekitar Desa Keputran, Kecamatan Sukoharjo, Kabupaten Pringsewu, Lampung.

\section{METODE PELAKSANAAN}

Kegiatan pengabdian berupa pendampingan pembuatan media sosial pemasaran batu nisan dan paving yang dilakukan di pusat home industry Pekon Keputran, Kecamatan Sukoharjo, Kabupaten Pringsewu. Pelaksanaan pendampingan diberikan kepada empat orang mitra pada tanggal 27 Juli - 14 Agustus 2020 oleh tim dosen dan mahasiswa dari STMIK Pringsewu.

berikut.

Pelaksanaan pengabdian menggunakan metode tutorial dengan tahapan sebagai

1) Perencanaan

Pada tahap ini, tim PKM STMIK Pringsewu melakukan survei lapangan di Pekon Keputran tentang kegiatan home industry potensial. Setelah menemukan home industry yang menjadi sasaran, tim melakukan koordinasi dengan mitra dan membuat jadwal pendampingan dengan persetujuan mitra pengabdian. Selanjutnya, tim membuat materi tentang pemanfaatan media sosial sebagai sarana pemasaran produk.

2) Pelaksanaan

Pada tahap ini, tim mengenalkan aplikasi media sosial yang dapat digunakan sebagai media promosi produk. Pelaksanaan pelatihan dan pendampingan juga melibatkan tiga orang mahasiswa STMIK Pringsewu untuk mengajarkan cara mempromosikan produk yang dihasilkan oleh pemilik UKM menggunakan media sosial.

3) Pendampingan

Tahap selanjutnya adalah mengetahui seberapa paham mitra terhadap cara mempromosikan barang menggunakan media sosial dengan melakukan praktek secara langsung, yaitu mulai dari pembuatan akun, membuat konten pemasaran baik gambar dan video yang menarik sampai pada posting konten secara periodik dan teratur.

4) Evaluasi

Setelah kegiatan pelaksanaan dan pendampingan selesai dilakukan, maka tim melakukan evaluasi terhadap hasil atau kendala yang ditemukan di lapangan.

\section{HASIL DAN PEMBAHASAN}

Pelatihan ini bertujuan untuk memberikan edukasi bagi mitra pelaku UKM agar memiliki keterampilan terhadap pemasaran produk kerajinan semen berupa paving block, goronggorong beton, dan batu nisan melalui promosi di media sosial yaitu facebook dan instagram. Pemasaran barang melalui media sosial merupakan cara yang sederhana namun sangat ampuh untuk mempromosikan barang dan jasa karena memberikan efek yang luar biasa bagi penggunanya. Salah satu contohnya adalah penggunaan Instagram yang mencapai 700 pengguna aktif setiap bulannya sehingga jangkauannya tidak diragukan lagi (Untari \& Fajariana, 2018).

Tahapan pelaksanaan dilakukan dengan metode tutorial yakni tim menjelaskan arti media sosial dan aplikasinya. Kendala mulai ditemukan saat mitra yang dihadapi tidak memiliki android pribadi (meminjam kepunyaan anaknya) dan gagap teknologi. Untuk menghadapi hal ini, tiap dosen mendampingi satu orang mitra secara intensif sehingga pengenalan dan langkah-langkah mulai dari men-download aplikasi dan membuat akun dapat tercapai pada pertemuan minggu pertama. 


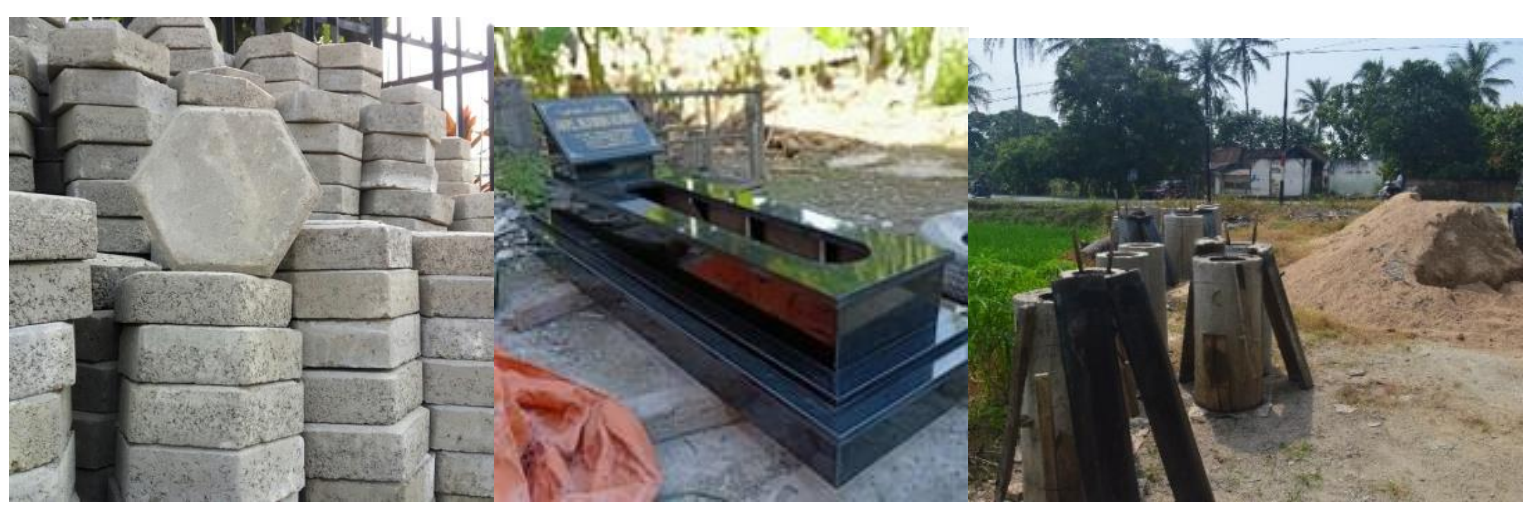

Gambar 1. Produk UKM paving, batu nisan, dan gorong-gorong

Pada kegiatan pengabdian di minggu kedua telah nampak kemajuan dari para mitra, hal ini terlihat dari cara memegang dan mengklik layar android yang tidak lagi kaku. Titik fokus pendampingan di minggu kedua adalah cara mengambil foto produk dan mengemas kalimat promosi yang singkat namun menarik. Tim melakukan metode tutorial dan memberikan berbagai contoh agar mudah dipahami mitra. Dalam pengambilan foto produk, tim memberikan penjelasan bahwa faktor sudut, zoom, dan pencahayaan menjadi salah satu faktor pendukung menghasilkan gambar produk yang jelas dan menarik dilihat. Untuk membuat foto lebih indah, tim juga memperkenalkan beberapa aplikasi editing foto yang tersedia di playstore begitu juga aplikasi meme untuk menyisipkan kalimat pada foto. Kendala usia dan penglihatan dari mitra yang berusia 50an tahun membuat tim lebih perlahan dalam menjelaskan agar materi dapat ditangkap.
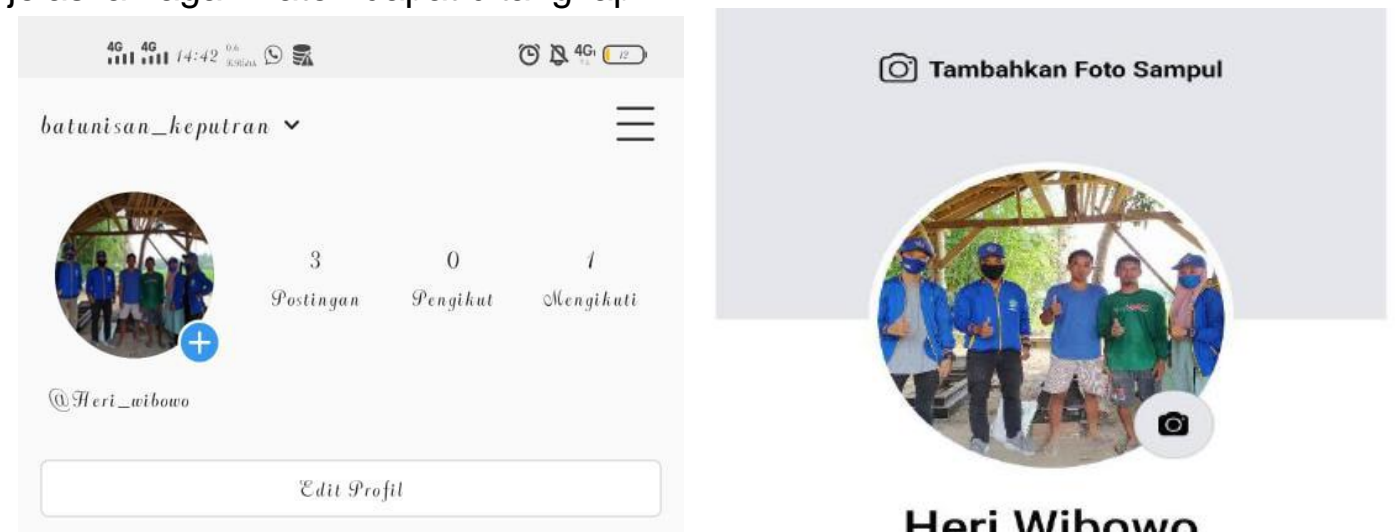

Heri Wibowo
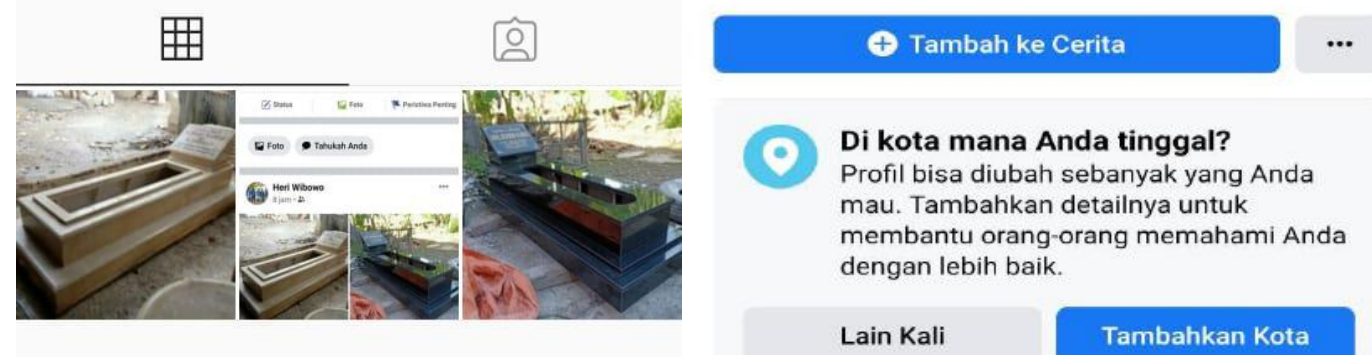

Gambar 2. Akun Instagram salah satu mitra dampingan

Fokus pengabdian pada minggu ketiga adalah mengamati dan mendampingi hasil pelatihan yang diberikan. Pada tahap ini, mitra telah mampu mencapai tujuan PKM yaitu memposting dan menyisipkan kalimat promosi pada produk UKM. Hal yang tidak kalah penting adalah mitra menyadari bahwa kemajuan teknologi digital memberikan pengaruh yang positif apabila digunakan dengan bijak. Hal ini sejalan dengan penelitian (Kurniawati \& Arifin, 2015) bahwa adanya media sosial memungkinkan para pelaku pasar untuk dapat berkomunikasi dengan sesama pengusaha atau konsumen. Media sosial juga memberikan kelebihan dalam 
pemasaran dengan menyebarkan pesan secara santai dan komunikatif karena para pengguna dapat berbalas pesan melalui aplikasi yang digunakan.

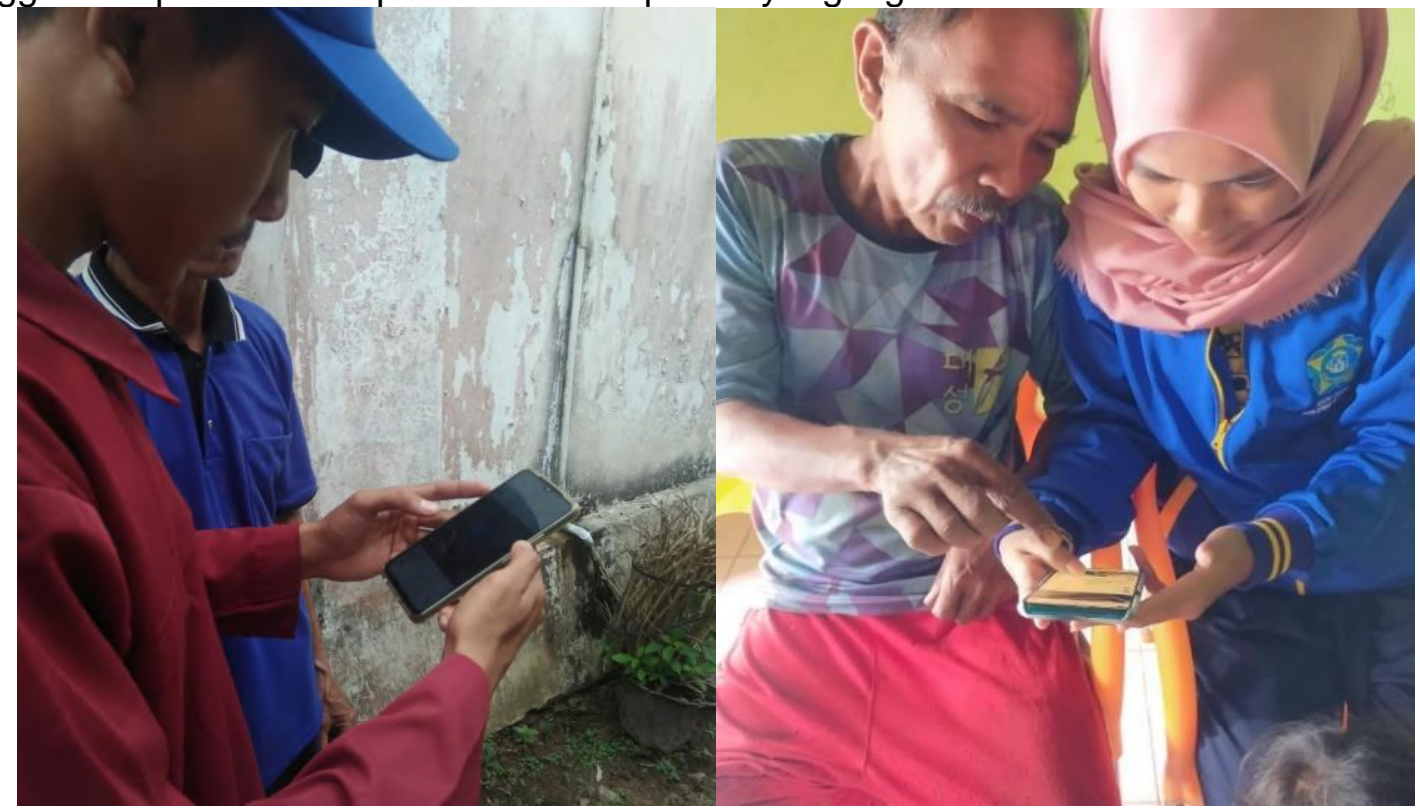

Gambar 3. Pendampingan mitra secara intensif selama tiga minggu

Dalam penyampaian materi, tim PKM memberikan ilustrasi bahwa semakin banyak "teman maya" yang dimiliki maka semakin besar peluang agar produk dikenali banyak orang. Tentu dari segi harga, hal ini dapat menjadi referensi bagi konsumen untuk mempertimbangkan. Dengan banyaknya penjual, menjadikan persaingan pasar yang sehat. Berdasarkan hasil penelitian yang dilakukan oleh Siswanto (2013) bahwa media sosial sebagai media pemasaran memberikan beberapa dampak positif terhadap UKM antara lain:

1) Media sosial sebagai integrated marketing communication yang memungkinkan pelaku UKM untuk dapat berkomunikasi dengan pelanggan yang telah ada ataupun calon pelangan baru.

2) Media sosial dapat dimanfaatkan sebagai media pemasaran secara gerilya karena sudah dilengkapi dengan berbagai fitur yang mampu memberikan fasilitas yang tidak kalah dari media lain yang membutuhkan biaya tinggi dalam penggunaanya.

3) Penggunaan media sosial dapat menciptakan brand image pagi UKM dan kepuasan bagi para pelanggan.

Lebih jauh Siswanto menambahkan, bahwa agar para pelaku UKM dapat mengikuti perkembangan informasi melalui media sosial maka perlu adanya peningkatan kapasitas SDM. Oleh karena itu, dalam kegiatan ini selain diberikan pelatihan penggunaan media sosial, mitra juga diberikan pelatihan tentang pembuatan gambar dan video yang menarik agar dapat menyampaikan informasi atau pesan-pesan dari konten yang diunggah kepada konsumen dengan baik. Maka pendampingan dilakukan agar mitra benar-benar bisa memanfaatkan media sosial sebagai media pemasaran. Hasil penelitian lainnya yang dilakukan oleh Marta \& William (2017) bahwa terpaan postingan instagram memberikan kontribusi sebesar $21,1 \%$ terhadap ekuitas merek, sedangkan sisanya dipengaruhi oleh variabel lain dari konsep komunikasi pemasaran yang belum diteliti. Hal ini terjadi karena dengan memberikan terpaan media baik dengan frekuensi, intensitas, dan durasi pemasaran akan lebih mudah memperkenalakan merek dagang kepada para konsumen serta meyakinkan kuliatas barang yang dijual. Oleh karena itu, pelaku UKM tidak boleh bosan dan selalu kreatif serta inovatif untuk memasarkan barangnya.

Dengan demikian, diperoleh hasil akhir dari kegiatan pelatihan dan pendampingan bahwa mitra yang tadinya gagap teknologi menjadi bisa menggunakan media sosial sebagai sarana pemasaran produk yang dihasilkan. Namun demikian, hal yang menjadi evaluasi adalah masih lemahnya akses koneksi internet di desa kegiatan PKM sehingga ke depan 
apabila kegiatan serupa dilakukan maka tim perlu menyediakan modem ataupun kartu GSM yang sesuai dengan keadaan lapangan.

\section{KESIMPULAN}

Berdasarkan pelatihan pemasaran produk kerajinan semen secara online yang dilakukan tim PKM diperoleh kesimpulan bahwa tim mampu mengajak mitra untuk melek teknologi dan mau memanfaatkan smartphone sebagai inovasi media untuk memasarkan produk. Setiap pertemuan, mitra berinisiatif menambah teman sebagai relasi yang baik, baik di Kabupaten Pringsewu maupun kabupaten/kota lain di wilayah Provinsi Lampung.

\section{REKOMENDASI}

Karena kegiatan ini dilakukan selama pandemi Covid-19 sehinggga pelaksanaan tidak dapat berjalan dengan maksimal. Untuk ke depannya semoga kegiatan serupa dapat diberikan kepada lebih banyak masyarakat pelaku home industry di Kabupaten Pringsewu.

\section{UCAPAN TERIMAKASIH}

Terima kasih kepada STMIK Pringsewu yang telah mendanai kegiatan pengabdian kepada masyarakat dan kepada mitra yang telah memberikan izin dan bersedia untuk diberikan pelatihan dan pendampingan.

\section{DAFTAR PUSTAKA}

Ananda, R., \& Ashaluddin, A. (2016). Peran Home Industri Dalam Meningkatkan Ekonomi Keluarga (Studi Kasus Home Industry Keripik. Riau University.

Danuri, M. (2019). Perkembangan dan transformasi teknologi digital. INFOKAM, 15(2).

Garaika, G. (2020). Pendampingan Wirausaha Mandiri Bagi Ibu Rumah Tangga Di Desa Pujorahayu Kecamatan Belitang. Jurnal PkM Pemberdayaan Masyarakat, 1(2), 33-40.

Hendro. (2011). Dasar-dasar Kewirausahaan (Panduan bagi Mahasiswa untuk Mengenal, Memahami, dan Memasuki Dunia Bisnis). Jakarta: Erlangga.

Kurniawati, D., \& Arifin, N. (2015). Strategi pemasaran melalui media sosial dan minat beli mahasiswa. JURNAL SIMBOLIKA: Research and Learning in Communication Study, $1(2)$.

Marta, R. F., \& William, D. M. W. M. (2017). Studi Terpaan Media Pemasaran Melalui Posting Instagram Terhadap Ekuitas Merek Pelanggan Sumoboo! Jurnal Komunikasi, 8(1), 6882.

Panggabean, D. D., Lubis, I., Hasibuan, A. F., Harahap, M. H., Irfandi, I., \& Syah, D. H. (2019). Pendampingan Industri Rumah Tangga Kuliner Roti di Desa Mangga Dua Kecamatan Tanjung Beringin Kabupaten Serdang Bedagai. Jurnal Pengabdian Kepada Masyarakat, 9(1), 61-69.

Risal, M. (2017). Produksi dan Pemasaran Produk Olahan Rumput Laut Home Industry Tanjung Ketupat Desa Munte Kecamatan Tana Lili Kabupaten Luwu Utara. RESONA: Jurnal Ilmiah Pengabdian Masyarakat, 1(1).

Siswanto, T. (2013). Optimalisasi sosial media sebagai media pemasaran usaha kecil menengah. Liquidity, 2(1), 80-86.

Tresnati, R., \& Maharani, N. (2014). Kajian tentang strategi pemasaran syariah dalam penguatan daya saing UKM menghadapi AEC 2015 di Indonesia. Proceedings SNEB, $1-11$.

Untari, D., \& Fajariana, D. E. (2018). Strategi Pemasaran Melalui Media Sosial Instagram (Studi Deskriptif Pada Akun@ Subur_Batik). Widya Cipta: Jurnal Sekretari Dan Manajemen, 2(2), 271-278. 